\title{
DOES EVA TRULY REFLECT THE PERFORMANCE OF PROPERTY COMPANIES IN CHINA?
}

\author{
Eddie C. M. HUI ${ }^{\text {a,*, Yunzhi Orange GAO }}{ }^{\text {a,b }}$, Ka Kwan Kevin CHAN a \\ ${ }^{a}$ Department of Building and Real Estate, The Hong Kong Polytechnic University, ZS725, South tower, \\ $7 / F$, Block Z, Hong Kong, China \\ ${ }^{b}$ Sun Hung Kai Properties Limited, 45th Floor, Sun Hung Kai Centre, 30 Harbour Road, Hong Kong, \\ China
}

Received 31 July 2013; accepted 3 October 2014

\begin{abstract}
This study investigates the economic value added (EVA) of 18 major Chinese property companies from 2006 to 2012 . We categorize the companies in two ways: 1) companies concentrating on property vs multi-functional companies and 2) state-owned enterprises (SOEs) vs privately-owned enterprises (POEs). We find that on average, the mainland property companies experienced a negative EVA during the period 2006-2012. This is due to the companies undertaking long-term projects, and the companies do not recognize capital gain from property appreciation as income. Hence the EVA of the companies is, in fact, understated. The results also reveal that POEs outperform SOEs in terms of EVA. This reflects the inefficiency of SOEs. This research has two important implications to investors. Firstly, besides looking at the EVA of the companies, investors should also understand the nature of businesses of the companies thoroughly. Secondly, investors investing in emerging markets like China should have a thorough understanding of their market characteristics. This study can act as a reference for future studies in EVA of property companies in other emerging economies in the world.
\end{abstract}

KEYWORDS: Property company; Performance measurement; China; ROIC; EVA

\section{INTRODUCTION}

China's economy has been undergoing tremendous transformation and rapid growth since its economic reform in late 1970s. With over 8\% GDP growth rate on average ${ }^{1}$, it surpassed Japan and became the second largest economy in the world just behind the U.S. in 2010. In particular, real estate has become one of the fastest growing areas since the Housing Policy Reform in 1998. Due to favorable policies towards the property sector and swift growth of the domestic economy in the new century, the commodity property market has been thriving in terms of both building area and market capital since 2001 . The commencing area surged from around 400 million $\mathrm{m}^{2}$ in 2001 to over 1.6 billion $\mathrm{m}^{2}$ in 2010 (Fig. 1). At the meantime, the total investment involving in property development increased by almost 8 times from 634 billion yuan to 4,826 billion yuan (Fig. 2). Therefore, investigating the performance

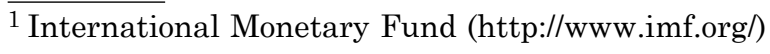

* Corresponding author. E-mail: bscmhui@polyu.edu.hk
}

of real estate developers in a proper way and identifying the booster behind are of extraordinary significance for investors to recognize investment opportunities.

Ooi and Liow (2002) and Hui et al. (2007) evaluated the economic performance of real estate developers in Singapore and Hong Kong respectively. Both articles adopted Economic Value Added (EVA) which has been advocated by numerous

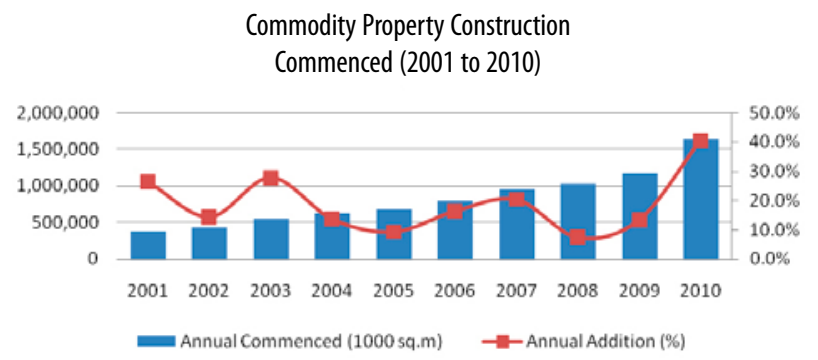

Fig. 1. Commodity property construction commenced (2001-2010)

Source: National Bureau of Statistics of China 
Investment in Commodity Property (2001 to 2010)

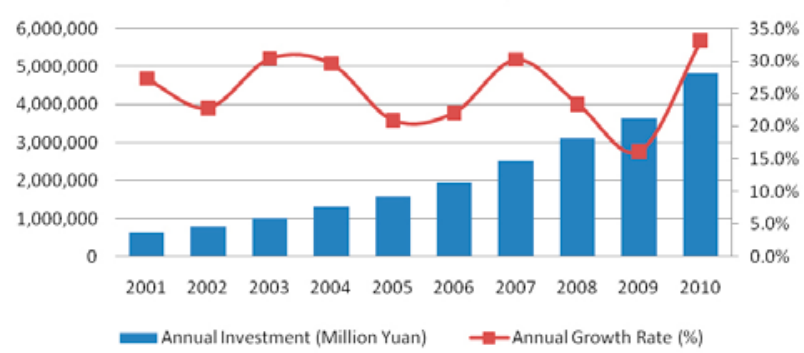

Fig. 2. Investment in commodity property (2001-2010) Source: National Bureau of Statistics of China

numbers of scholars and corporate governors as an effective way to evaluate companies' performance since its invention in 1989. This paper examines EVA of property companies in China, of which only a few studies investigated on. Unlike Hong Kong, China is still a planned economy. Although the Chinese government has continued to open up its market since the open-door policy was implemented in 1978, the government remains certain control over the market. Therefore, Chinese companies may have different EVA from those companies operating in market economies like Hong Kong. In particular, many Chinese enterprises are still owned by the government. These state-owned enterprises' (SOEs') EVA may be different from those privately-owned enterprises' (POEs'). This study aims to fill in this gap.

This paper proceeds as follows: Section 2 gives a literature review of previous studies on EVA. Section 3 gives a brief description of EVA and other performance measurement tools. Section 4 describes the data source. Section 5 presents the results. Section 6 further explains the implication of the results. Finally, a conclusion is drawn in Section 7.

\section{LITERATURE REVIEW}

According to modern corporate finance theory, the ultimate goal of a company is to maximize shareholders' profit. Economic value added (EVA) is identified as an effective measure to assess corporate performance.

The definition of EVA was not renowned and well-adopted as it is nowadays when first proposed by Finegan in 1989 (Chen, Dodd 1997). However, an article in Fortune magazine called "The Real Key to Creating Wealth" by Tully (1993) made it in the spotlight. The article strongly praised EVA as the most exciting innovation in gauging corporate success. The possible adoption of EVA started to attract the attention of management in international corporations. Proponents of EVA at that time include Coca-Cola, CSX, Compaq Computer, and so on. Through over 20 years of development, discussion and verification, the idea of EVA is now considered to be one of the important selection criteria for investors and managers to measure corporations' economic performance all over the world. Besides foreign conglomerates, the metric has been adopted by domestic property developers such as Vanke and Gemdale to enhance capital utilization and stock performance.

There are a number of studies on EVA in the past. For example, Chen and Dodd (1997) examine the EVA of 566 U.S. companies and compare the information usefulness of EVA with accounting earnings and residual income. They find that EVA is more powerful than traditional measures of accounting profit in explaining stock return. Moreover, not only is EVA similar to residual income in concept, but also the two metrics are empirically comparable. Ooi and Liow (2002) track the performance of Singapore property companies, and claim that their actual performance is understated in terms of EVA. Hui et al. (2007) replicate the above study for Hong Kong property market. They find that the multi-functional groups generally outperformed those with sole business focus on real estate development and management. Liow and Ooi (2004) examine the influence of corporate real estate (CRE) on shareholder value using EVA and market value added (MVA). They find that if a firm has a higher the real estate asset intensity, it will have lower EVA and MVA. In addition, there are also other studies on EVA (e.g. Milunovich, Tsuei 1996; Anctil et al. 1998; O'Hanlon, Peasnell 1998; Demodaran 1999; Biddle et al. 1997; Peasnell 1982).

There are only a few studies on performance measure of China's real estate companies. Zheng et al. (2010) measure the performance and efficiency of 94 Listed Real Estate Companies (LRECs) in Mainland China by three types of Data Envelopment Analysis (DEA), namely CCR-DEA, BCCDEA and Super-Efficiency-DEA models. They find out that $69 \%$ of the inefficient LRECs in China are dominated by increasing returns to scale, which implies that these companies can further increase their operating efficiency through expansion. Ke (2008) investigates the state-owned property developers in China using annual stock returns (SR) as the market performance indicator, the natural logarithm return on equity (ROE (Ln)) as the accounting performance indicator, and the ratio of 
selling, general and administration costs to sales (SG\&A to sale) as operating efficiency indicators. He finds no evidence that the operation of stateowned developers is inefficient. The performance of private developers in China, however, is not measured in a quantitative means.

According to Sharma and Kumar (2010), out of the total of 112 articles on EVA, the country with the largest number of articles studying on was USA, with a number of 51 articles (or $45 \%$ of total) studying on this country. India ranked the second with 21 articles (or $19 \%$ of total) studying on it. In contrary, only two articles studied EVA of companies in China (see Table 1): Liao and Feng (2005) and Chen and Qiao (2008). However, both articles are just empirical studies on EVA of Chinese companies in general, without focusing on a particular field of business. Moreover, they do not capture the most recent information. On the other hand, our study investigates the EVA of mainland property companies from 2006 to 2012. In particular, we divide the companies into two classes, state-owned enterprises (SOEs) and privately-owned enterprises (POEs). SOEs are owned by the government and exist only in planned economies like China. They may behave differently from POEs in terms of EVA. Hence our study can bridge the gap.

Besides, Sharma and Kumar (2010) also found that a large proportion of the previous studies investigated the adoption of EVA in the manufacturing industry, and to some extent overlooked the application in other fields like the real estate industry. Thus, they appealed that using EVA approach to measure the performance of non-manufacturing industries in emerging counties may be another area for future research.

Table 1. Country-wise publication of studies on EVA (Sharma, Kumar 2010)

\begin{tabular}{lll}
\hline S. No. & Country & No. of studies conducted \\
\hline 1 & USA & 51 \\
2 & India & 21 \\
3 & South Africa & 8 \\
4 & Australia & 5 \\
5 & UK & 2 \\
& China & 2 \\
6 & Others* & 23 \\
\hline
\end{tabular}

Note: * Other includes Malaysia, Canada, Brazil, Greece, Russia, New Zealand, Kuwait, Turkey, Indonesia, etc.

From the above literature review, it is noted that although performance of property firms in developed Asian economies such as Hong Kong and Singapore has been well discussed by scholars, there are still no publications on performance of real estate companies in China in terms of EVA. In order to fill in this gap, this study examines EVA of major mainland property companies from 2006 to 2012 .

\section{PERFORMANCE MEASUREMENT TOOLS}

\subsection{Traditional measures}

Traditionally, the following measures are commonly used to evaluate the performance of a firm:

- Accounting profit;

- Earnings per share $($ EPS $)=$ Net profit $/$ Total number of shares;

- Return on equity $(\mathrm{ROE})=$ Net profit/Equity (or any other accounting rate of return like return on investment (ROI), return on asset (ROA), etc.).

The above measures indicate a firm's profitability. However, according to Ooi and Liow (2002), higher accounting profit does not necessarily mean that deployment of capital is more efficient. Since no cost is imputed for the use of equity capital, the real cost of business is understated. This may lead to an illusion of cheap equity capital. Moreover, the policy of maximizing ROI (or ROE) does not always encourage managers to make decisions aligned with the goals of the company (Brewer et al. 1999; Ooi, Liow 2002). Ooi and Liow (2002) raised the following example: if financial compensation is linked to ROI or ROE, a manager has no incentive to pursue investments yielding positive returns, but at a lower rate than what is currently achieved due to potential earnings dilution. Instead, projects with high returns potential may be favored at the expense of exposing the company to unduly high risk. This disadvantage leads to the invention of EVA, which can reflect shareholders' value more truly.

\subsection{EVA}

EVA, registered by Stern Stewart \& Co, is used in this study to measure the economic profit of real estate companies. Unlike other traditional financial performance indicators like ROI/ROE/EPS, EVA measures the residual wealth by deducting cost of capital from net operating profit. The rationale behind this is that only when the profit generating from the company's total capital invested exceeds the cost of capital employed can shareholders' value be created. Otherwise, the company is deemed to have destroyed shareholders' value. In view of corporate finance, the former can be represented by net operating profit after tax (NOPAT), while the later can be represented by weighted average 
cost of capital (WACC) multiplied by the total capital invested (IC). The advantage of EVA is that it helps the management and employees to understand the real cost of equity capital, and hence lowers the chance that management misuses free cash flow in unprofitable investments (Makelainen 1998; Ooi, Liow 2002). Since EVA adopts the residual income approach, it is consistent with the general rule of accepting a project with positive NPV. A further advantage raised by Ooi and Liow (2002) is that when compensation is linked with EVA, the goals of employees, managers the entire company are tied together, reducing the conflict of interests between the management and shareholders (Wallace 1997), i.e. the agency problem.

The most commonly adopted formula for EVA calculation is (also adopted in this paper):

$\mathrm{EVA}=$ NOPAT $-\mathrm{WACC} * \mathrm{IC}=($ ROIC $-\mathrm{WACC}) * \mathrm{IC},(1)$ where: NOPAT - net operating profit after tax; WACC - weighted average cost of capital; IC - total invested capital; ROIC $=$ NOPAT/IC - return on capital invested.

Note that NOPAT is used to measure a company's operating profit deducting tax for stockholders and debt holders. ROIC is used to estimate how well a company generates profit compared with the total capital invested in the business. A higher ROIC usually indicates higher profitability. Meanwhile, WACC denotes the ratio that a company is paid to its debt and equity holders to fund its total capital. It also suggests the minimum return rate

Table 2. The 18 selected mainland property companies

\begin{tabular}{|c|c|c|c|c|c|c|}
\hline \multirow[t]{2}{*}{ Company name } & \multirow{2}{*}{$\begin{array}{l}\text { Stock } \\
\text { code }\end{array}$} & \multirow{2}{*}{$\begin{array}{l}\text { Place of } \\
\text { listing }\end{array}$} & \multicolumn{2}{|c|}{ Scope of business } & \multicolumn{2}{|c|}{ Ownership } \\
\hline & & & Concentration & Diversification & $\mathrm{SOE}$ & $\mathrm{POE}$ \\
\hline China Overseas Land \& Investment Ltd. & 00688 & Hong Kong & $\mathrm{X}$ & & $\mathrm{X}$ & \\
\hline Greentown China Holdings Ltd. & 03900 & Hong Kong & $\mathrm{X}$ & & & $\mathrm{X}$ \\
\hline Hopson Development Holdings Ltd. & 00754 & Hong Kong & $\mathrm{X}$ & & & $\mathrm{X}$ \\
\hline Guangzhou R\&F Properties Co Ltd. & 02777 & Hong Kong & $\mathrm{X}$ & & & $\mathrm{X}$ \\
\hline China Resources Land Ltd. & 01109 & Hong Kong & $\mathrm{X}$ & & $\mathrm{x}$ & \\
\hline Shenzhen Investment Ltd. & 00604 & Hong Kong & & $\mathrm{X}$ & $\mathrm{X}$ & \\
\hline SRE Group Ltd. & 01207 & Hong Kong & $\mathrm{X}$ & & & $\mathrm{X}$ \\
\hline Shenzhen Overseas Chinese Town Co Ltd. & 000069 & Shenzhen & & $\mathrm{X}$ & $\mathrm{X}$ & \\
\hline Suning Universal Co Ltd. & 000718 & Shenzhen & & $\mathrm{X}$ & $\mathrm{X}$ & \\
\hline Financial Street Holdings Co Ltd. & 000402 & Shenzhen & & $\mathrm{X}$ & $\mathrm{x}$ & \\
\hline China Merchants Property Development Co Ltd. & 000024 & Shenzhen & $\mathrm{X}$ & & $\mathrm{X}$ & \\
\hline Yinyi Real Estate Co Ltd. & 000981 & Shenzhen & $\mathrm{X}$ & & $\mathrm{X}$ & \\
\hline Hubei Fuxing Science And Technology Co Ltd. & 000926 & Shenzhen & & $\mathrm{X}$ & $\mathrm{X}$ & \\
\hline Gemdale Corporation & 600383 & Shanghai & $\mathrm{X}$ & & & $\mathrm{X}$ \\
\hline Beijing Capital Development Co Ltd. & 600376 & Shanghai & $\mathrm{X}$ & & $\mathrm{X}$ & \\
\hline Tianjin Reality Development Group Co Ltd. & 600322 & Shanghai & $\mathrm{X}$ & & $\mathrm{X}$ & \\
\hline Xiamen C \& D Inc. & 600153 & Shanghai & & $\mathrm{X}$ & $\mathrm{X}$ & \\
\hline Jiangsu Future Land Co Ltd. & 900950 & Shanghai & $\mathrm{X}$ & & & $\mathrm{X}$ \\
\hline
\end{tabular}

the company is required to earn for the purpose of satisfying all the security holders. An increase in WACC for a company denotes a decrease in valuation and a higher risk.

EVA can act as an indicator of a company's economic profit. Positive EVA means that the value created by operating activities exceeds the required rate of return by the company's investors, and vice versa. When EVA is used to measure a company's real profitability, the increase in EVA means that the company is able to boost operating profits in spite of involving more capital; to invest in developments which generate more than the cost of investment; or to involve less investment for the identical level of business.

\section{DATA SOURCE}

We select property companies in Mainland China according to the following criteria:

(a) The companies rank among top 50 of the largest real estate companies in Mainland China.

(b) During the period 2006-2012, not less than $50 \%$ of revenue of the companies came from real estate, and the core property businesses of all the companies are in Mainland China.

(c) The companies were listed on the Shenzhen Stock Exchange (SZSE), Shanghai Stock Exchange (SSE) or Hong Kong Stock Exchange (HKSE) no later than 2006. 
(d) The year-end date of the companies is $31 \mathrm{De}$ cember.

After selecting the companies, we obtain the following fields of data of those companies each year during the period 2006-2012 from Bloomberg:

(i) ROIC (Bloomberg code: WACC_RETURN_ ON_INV_CAPITAL),

(ii) WACC (Bloomberg code: WACC),

(iii) ROIC - WACC (Bloomberg code: WACC_ EVA_SPREAD),

(iv) EVA (Bloomberg code: WACC_ECON_VALUE_ADDED) (all the values are converted to RMB).

A total of only 18 companies are chosen because they are the only companies which fulfill all the three criteria (a) to (d), and their fields of data (i) to (iv) from 2006 to 2012 can be obtained from Bloomberg.

We classify the 18 selected companies by the following two ways:

1. Companies concentrating their business solely on property development, building construction, leasing, property management, hotel investment, etc. ("Concentration") vs Companies with a primary focus on property, but also expose to other sectors of business ("Diversification").

2. State-owned enterprises (SOEs) vs Privatelyowned enterprises (POEs).

Table 2 shows the 18 selected companies and their classification by the above two ways.

\section{RESULTS AND FINDINGS}

Tables 3, 4, 5 and 6 display the EVA, ROIC, WACC, ROIC-WACC of the 18 selected mainland property companies during the period 2006-2012 respectively. From Table 3, we can see that except for Jiangsu Future Land Co Ltd., all other 17 companies recorded a negative average EVA during the period. In each of the year during the period, the average EVA of the 18 companies is negative. The magnitude of negativity of the average EVA was not so great in 2006 and 2007, but since 2008, the average EVA of the 18 companies has stayed below RMB -600 million, and even plunged to a trough of about RMB -1400 million in 2011. It seems that the companies did not perform so well in terms of EVA during the period. To look deeper into the real picture, we consider the ROIC, WACC, and the gap between ROIC and WACC of the 18 companies during the period.

Table 4 shows the ROIC of the 18 companies during the period. From the table, although the ROIC of different companies varied during the period, the average ROIC of the 18 companies remained rather stable during the period, except for year 2008, when the average ROIC of the companies fell to a minimum of $1.50 \%$, mainly due to the effect of the global financial tsunami in that year which significantly hurt the profitability of many companies worldwide. For the other years in the period, the average ROIC of the companies remained within a stable range from $5.23 \%$ to $6.51 \%$.

Table 3. EVA of the 18 mainland property companies during the period 2006-2012 (unit: million RMB)

\begin{tabular}{|c|c|c|c|c|c|c|c|c|}
\hline Stock code & 2006 & 2007 & 2008 & 2009 & 2010 & 2011 & 2012 & Average \\
\hline 00688 & -414.56 & -1274.08 & -408.98 & 742.12 & 4018.95 & -5224.42 & -1737.46 & -614.06 \\
\hline 03900 & 927.14 & -221.36 & -583.96 & -2224.24 & -2127.06 & 119.49 & 86.04 & -574.85 \\
\hline 00754 & 304.24 & 3074.22 & -2160.34 & -1217.73 & -1585.48 & -2856.53 & -4660.83 & -1300.35 \\
\hline 02777 & 827.71 & 30.08 & 63.48 & -1924.89 & -17.67 & -709.28 & 673.99 & -150.94 \\
\hline 01109 & -1980.19 & -4376.74 & -3859.31 & -3309.83 & -689.09 & -4458.90 & -4313.59 & -3283.95 \\
\hline 00604 & -695.10 & -1551.22 & -358.42 & -1165.25 & -856.01 & -791.82 & -702.44 & -874.32 \\
\hline 01207 & 73.05 & -501.19 & 207.37 & -574.08 & -252.93 & -49.19 & -368.55 & -209.36 \\
\hline 000069 & -212.41 & -657.17 & -532.62 & -110.51 & -656.54 & -2263.77 & -2137.37 & -938.63 \\
\hline 000718 & 21.32 & -64.15 & 229.07 & 129.07 & -238.32 & -442.28 & -479.81 & -120.73 \\
\hline 000402 & -41.38 & 388.31 & -1390.82 & -2556.45 & -2068.89 & -1958.22 & -1426.54 & -1293.43 \\
\hline 000024 & -775.84 & -636.38 & -2019.37 & -1800.66 & -1330.16 & -1091.44 & -806.23 & -1208.58 \\
\hline 000981 & -73.12 & -158.64 & -236.83 & -85.44 & 7.84 & -153.15 & -219.93 & -131.32 \\
\hline 000926 & 0.06 & 60.13 & -97.51 & -441.25 & -929.79 & -772.91 & -656.20 & -405.35 \\
\hline 600383 & -208.37 & -596.86 & -531.81 & -1926.64 & -1890.36 & -1510.13 & -1432.08 & -1156.61 \\
\hline 600376 & -654.01 & 200.73 & -253.60 & -2049.38 & -2290.14 & -2096.78 & -2342.89 & -1355.15 \\
\hline 600322 & -197.27 & -89.79 & -439.18 & -712.81 & -571.59 & -467.08 & -529.02 & -429.53 \\
\hline 600153 & -46.64 & -170.09 & 167.34 & -399.19 & -111.54 & -642.12 & -413.75 & -230.86 \\
\hline 900950 & 165.61 & 194.65 & 168.21 & 13.11 & -99.77 & 63.95 & 303.96 & 115.67 \\
\hline Average & -165.54 & -352.75 & -668.74 & -1089.67 & -649.36 & -1405.81 & -1175.71 & -786.80 \\
\hline
\end{tabular}


Table 5 shows the WACC of the 18 companies during the period. From the table, the average WACC of the 18 companies remained between $7.28 \%$ and $8.37 \%$ from 2006 to 2008 . In 2009 , the companies' average WACC reached a maximum of $10.28 \%$. The average WACC of the companies remained around $9 \%$ in the following three years, which is higher than the level in 2006-2008. As explained in Section 3, an increase in WACC indicated higher risk. The higher level of WACC of the companies since 2009 indicated a higher level of risk of the companies since then. This may be due to the global financial tsunami in late 2008 which increased the risk of most companies. This is reflected by the higher level of WACC of the companies since 2009. This effect persisted until 2012 as the Euro crisis, an aftershock of the global financial tsunami, broke out in 2010, keeping the companies at high risk.

Table 4. ROIC of the 18 mainland property companies during the period 2006-2012

\begin{tabular}{|c|c|c|c|c|c|c|c|c|}
\hline Stock code & 2006 & 2007 & 2008 & 2009 & 2010 & 2011 & 2012 & Average \\
\hline 00688 & $8.34 \%$ & $9.39 \%$ & $6.94 \%$ & $10.42 \%$ & $12.82 \%$ & $6.43 \%$ & $10.20 \%$ & $9.22 \%$ \\
\hline 03900 & $11.15 \%$ & $3.58 \%$ & $1.58 \%$ & $1.88 \%$ & $2.45 \%$ & $5.16 \%$ & $10.31 \%$ & $5.16 \%$ \\
\hline 00754 & $10.23 \%$ & $18.43 \%$ & $-0.86 \%$ & $5.63 \%$ & $5.72 \%$ & $1.74 \%$ & $1.39 \%$ & $6.04 \%$ \\
\hline 02777 & $11.44 \%$ & $11.79 \%$ & $7.02 \%$ & $4.65 \%$ & $9.05 \%$ & $7.19 \%$ & $9.39 \%$ & $8.65 \%$ \\
\hline 01109 & $2.66 \%$ & $3.93 \%$ & $3.52 \%$ & $5.45 \%$ & $6.95 \%$ & $5.81 \%$ & $7.05 \%$ & $5.05 \%$ \\
\hline 00604 & $3.28 \%$ & $1.05 \%$ & $2.65 \%$ & $2.83 \%$ & $4.15 \%$ & $3.09 \%$ & $4.35 \%$ & $3.06 \%$ \\
\hline 01207 & $10.26 \%$ & $5.42 \%$ & $5.08 \%$ & $2.94 \%$ & $3.96 \%$ & $2.47 \%$ & $0.59 \%$ & $4.39 \%$ \\
\hline 000069 & $4.03 \%$ & $1.86 \%$ & $6.61 \%$ & $12.35 \%$ & $9.38 \%$ & $7.12 \%$ & $7.17 \%$ & $6.93 \%$ \\
\hline 000718 & $8.86 \%$ & $8.27 \%$ & $18.50 \%$ & $17.04 \%$ & $11.57 \%$ & $9.35 \%$ & $8.56 \%$ & $11.74 \%$ \\
\hline 000402 & $7.34 \%$ & $10.27 \%$ & $3.35 \%$ & $2.55 \%$ & $3.91 \%$ & $4.01 \%$ & $4.79 \%$ & $5.17 \%$ \\
\hline 000024 & $-0.30 \%$ & $5.36 \%$ & $1.30 \%$ & $5.02 \%$ & $6.88 \%$ & $5.93 \%$ & $8.32 \%$ & $4.64 \%$ \\
\hline 000981 & $-6.27 \%$ & $-24.30 \%$ & $-64.53 \%$ & $-7.74 \%$ & $5.70 \%$ & $9.02 \%$ & $6.48 \%$ & $-11.66 \%$ \\
\hline 000926 & $7.33 \%$ & $7.67 \%$ & $6.42 \%$ & $5.51 \%$ & $3.72 \%$ & $4.19 \%$ & $5.11 \%$ & $5.71 \%$ \\
\hline 600383 & $5.23 \%$ & $7.57 \%$ & $4.82 \%$ & $5.82 \%$ & $6.72 \%$ & $6.33 \%$ & $7.21 \%$ & $6.24 \%$ \\
\hline 600376 & $-0.79 \%$ & $4.65 \%$ & $4.36 \%$ & $2.68 \%$ & $3.46 \%$ & $4.29 \%$ & $3.34 \%$ & $3.14 \%$ \\
\hline 600322 & $1.00 \%$ & $1.37 \%$ & $1.95 \%$ & $1.35 \%$ & $1.85 \%$ & $5.05 \%$ & $4.08 \%$ & $2.38 \%$ \\
\hline 600153 & $6.38 \%$ & $6.16 \%$ & $8.40 \%$ & $6.76 \%$ & $7.62 \%$ & $6.89 \%$ & $7.22 \%$ & $7.06 \%$ \\
\hline 900950 & $12.89 \%$ & $11.71 \%$ & $9.88 \%$ & $9.95 \%$ & $7.04 \%$ & $8.60 \%$ & $11.56 \%$ & $10.23 \%$ \\
\hline Average & $5.72 \%$ & $5.23 \%$ & $1.50 \%$ & $5.28 \%$ & $6.28 \%$ & $5.70 \%$ & $6.51 \%$ & $5.18 \%$ \\
\hline
\end{tabular}

Table 5. WACC of the 18 mainland companies during the period 2006-2012

\begin{tabular}{lllllllll}
\hline Stock code & 2006 & 2007 & 2008 & 2009 & 2010 & 2011 & 2012 & Average \\
\hline 00688 & $10.03 \%$ & $12.51 \%$ & $7.69 \%$ & $9.18 \%$ & $8.49 \%$ & $11.98 \%$ & $11.64 \%$ & $10.22 \%$ \\
03900 & $3.88 \%$ & $4.60 \%$ & $3.51 \%$ & $7.69 \%$ & $6.65 \%$ & $4.97 \%$ & $10.14 \%$ & $5.92 \%$ \\
00754 & $8.44 \%$ & $10.06 \%$ & $4.74 \%$ & $8.29 \%$ & $8.35 \%$ & $5.78 \%$ & $7.83 \%$ & $7.64 \%$ \\
02777 & $6.57 \%$ & $11.70 \%$ & $6.86 \%$ & $9.09 \%$ & $9.09 \%$ & $8.56 \%$ & $8.34 \%$ & $8.60 \%$ \\
01109 & $11.50 \%$ & $15.39 \%$ & $11.57 \%$ & $10.91 \%$ & $7.84 \%$ & $9.92 \%$ & $10.98 \%$ & $11.16 \%$ \\
00604 & $7.72 \%$ & $8.85 \%$ & $4.30 \%$ & $8.09 \%$ & $4.15 \%$ & $5.90 \%$ & $6.35 \%$ & $6.48 \%$ \\
01207 & $9.18 \%$ & $9.56 \%$ & $3.60 \%$ & $5.96 \%$ & $5.09 \%$ & $2.67 \%$ & $2.55 \%$ & $5.52 \%$ \\
000069 & $7.38 \%$ & $8.04 \%$ & $9.03 \%$ & $12.96 \%$ & $11.38 \%$ & $12.27 \%$ & $11.88 \%$ & $10.42 \%$ \\
000718 & $6.58 \%$ & $10.76 \%$ & $11.59 \%$ & $14.40 \%$ & $14.62 \%$ & $14.33 \%$ & $13.73 \%$ & $12.29 \%$ \\
000402 & $7.93 \%$ & $6.92 \%$ & $9.15 \%$ & $10.06 \%$ & $9.18 \%$ & $8.81 \%$ & $7.66 \%$ & $8.53 \%$ \\
000024 & $7.73 \%$ & $8.72 \%$ & $8.35 \%$ & $11.77 \%$ & $10.79 \%$ & $8.32 \%$ & $9.86 \%$ & $9.36 \%$ \\
000981 & $6.42 \%$ & $5.24 \%$ & $8.61 \%$ & $13.23 \%$ & $5.55 \%$ & $11.06 \%$ & $8.52 \%$ & $8.38 \%$ \\
000926 & $7.33 \%$ & $6.53 \%$ & $7.93 \%$ & $11.08 \%$ & $11.03 \%$ & $9.28 \%$ & $9.51 \%$ & $8.95 \%$ \\
600383 & $8.07 \%$ & $10.97 \%$ & $7.13 \%$ & $11.50 \%$ & $10.93 \%$ & $9.07 \%$ & $9.53 \%$ & $9.60 \%$ \\
600376 & $3.96 \%$ & $3.25 \%$ & $6.22 \%$ & $11.57 \%$ & $11.43 \%$ & $9.89 \%$ & $8.71 \%$ & $7.86 \%$ \\
600322 & $6.36 \%$ & $2.74 \%$ & $7.28 \%$ & $10.77 \%$ & $10.70 \%$ & $11.65 \%$ & $10.33 \%$ & $8.55 \%$ \\
600153 & $7.13 \%$ & $7.96 \%$ & $7.34 \%$ & $8.83 \%$ & $8.04 \%$ & $8.76 \%$ & $8.28 \%$ & $8.05 \%$ \\
900950 & $6.04 \%$ & $6.79 \%$ & $6.22 \%$ & $9.69 \%$ & $8.11 \%$ & $8.06 \%$ & $9.02 \%$ & $7.70 \%$ \\
Average & $7.35 \%$ & $8.37 \%$ & $7.28 \%$ & $10.28 \%$ & $8.97 \%$ & $8.96 \%$ & $9.16 \%$ & $8.62 \%$ \\
\hline
\end{tabular}


Comparing the results in Tables 4 and 5, for each year in the period 2006-2012, the average ROIC of the 18 companies is lower than their average WACC. Therefore, from Table 6, which shows the gap between ROIC and WACC of the 18 companies during the period 2006-2012, we can see that the average value of ROIC - WACC of the companies remained negative throughout the period. Hence by formula (1), the average EVA of the companies also remained negative throughout the period. The average value of ROIC - WACC bottomed at $-5.78 \%$ in 2008 and rebounded to $-3.26 \%$ to $-2.65 \%$ in $2010-2012$, but the average EVA fell to a trough of about RMB - 1400 million in 2011, and remained low at nearly RMB -1200 in 2012 . During the period 2006-2012, the decrease in EVA is much greater than the decrease in ROIC WACC. From formula (1), this reveals that the total invested capital (IC) of the companies has increased over the period, i.e. the companies were in a stage of expansion over the period. When ROIC-WACC is negative, a higher level of IC would make the value of EVA even more negative.

From Table 7, during the period 2006-2012, multifunctional companies have a higher EVA than those concentrating on real estate. According to Hui et al. (2007), when a company diversifies its investment, part of its revenue can be generated and received earlier from other business ventures due to their relatively shorter-term nature, causing better economic performance. Hui et al. (2007) found that Hong Kong property companies diversifying into other sectors appeared to outperform those focused solely in real estate. Liow and Ooi (2004) also showed that a higher intensity of real estate assets of a company would lead to a lower EVA.

As shown in Table 8, during the period 20062012, POEs enjoyed a higher ROIC and a lower WACC than SOEs. Hence they experienced a

Table 6. ROIC - WACC of the 18 mainland companies during the period 2006-2012

\begin{tabular}{lllllllll}
\hline Stock code & 2006 & 2007 & 2008 & 2009 & 2010 & 2011 & 2012 & Average \\
\hline 00688 & $-1.70 \%$ & $-3.12 \%$ & $-0.75 \%$ & $1.25 \%$ & $4.33 \%$ & $-5.55 \%$ & $-1.44 \%$ & $-1.00 \%$ \\
03900 & $7.26 \%$ & $-1.02 \%$ & $-1.94 \%$ & $-5.82 \%$ & $-4.20 \%$ & $0.18 \%$ & $0.17 \%$ & $-0.77 \%$ \\
00754 & $1.79 \%$ & $8.37 \%$ & $-5.60 \%$ & $-2.66 \%$ & $-2.63 \%$ & $-4.04 \%$ & $-6.44 \%$ & $-1.60 \%$ \\
02777 & $4.87 \%$ & $0.09 \%$ & $0.17 \%$ & $-4.44 \%$ & $-0.04 \%$ & $-1.37 \%$ & $1.06 \%$ & $0.05 \%$ \\
01109 & $-8.85 \%$ & $-11.46 \%$ & $-8.05 \%$ & $-5.45 \%$ & $-0.89 \%$ & $-4.10 \%$ & $-3.94 \%$ & $-6.11 \%$ \\
00604 & $-4.44 \%$ & $-7.80 \%$ & $-1.65 \%$ & $-5.26 \%$ & $0.00 \%$ & $-2.81 \%$ & $-2.00 \%$ & $-3.42 \%$ \\
01207 & $1.09 \%$ & $-4.14 \%$ & $1.48 \%$ & $-3.02 \%$ & $-1.13 \%$ & $-0.20 \%$ & $-1.96 \%$ & $-1.13 \%$ \\
000069 & $-3.35 \%$ & $-6.18 \%$ & $-2.42 \%$ & $-0.61 \%$ & $-1.99 \%$ & $-5.15 \%$ & $-4.71 \%$ & $-3.49 \%$ \\
000718 & $2.28 \%$ & $-2.49 \%$ & $6.92 \%$ & $2.64 \%$ & $-3.05 \%$ & $-4.98 \%$ & $-5.17 \%$ & $-0.55 \%$ \\
000402 & $-0.59 \%$ & $3.35 \%$ & $-5.80 \%$ & $-7.51 \%$ & $-5.28 \%$ & $-4.80 \%$ & $-2.87 \%$ & $-3.36 \%$ \\
000024 & $-8.03 \%$ & $-3.37 \%$ & $-7.06 \%$ & $-6.75 \%$ & $-3.91 \%$ & $-2.39 \%$ & $-1.54 \%$ & $-4.72 \%$ \\
000981 & $-12.69 \%$ & $-29.54 \%$ & $-73.14 \%$ & $-20.97 \%$ & $0.15 \%$ & $-2.05 \%$ & $-2.05 \%$ & $-20.04 \%$ \\
000926 & $0.00 \%$ & $1.15 \%$ & $-1.51 \%$ & $-5.57 \%$ & $-7.31 \%$ & $-5.09 \%$ & $-4.41 \%$ & $-3.25 \%$ \\
600383 & $-2.84 \%$ & $-3.40 \%$ & $-2.31 \%$ & $-5.68 \%$ & $-4.20 \%$ & $-2.74 \%$ & $-2.32 \%$ & $-3.36 \%$ \\
600376 & $-4.75 \%$ & $1.41 \%$ & $-1.86 \%$ & $-8.89 \%$ & $-7.97 \%$ & $-5.60 \%$ & $-5.37 \%$ & $-4.72 \%$ \\
600322 & $-5.36 \%$ & $-1.37 \%$ & $-5.32 \%$ & $-9.42 \%$ & $-8.85 \%$ & $-6.61 \%$ & $-6.25 \%$ & $-6.17 \%$ \\
600153 & $-0.75 \%$ & $-1.79 \%$ & $1.07 \%$ & $-2.07 \%$ & $-0.42 \%$ & $-1.86 \%$ & $-1.06 \%$ & $-0.98 \%$ \\
900950 & $6.84 \%$ & $4.92 \%$ & $3.66 \%$ & $0.26 \%$ & $-1.07 \%$ & $0.54 \%$ & $2.54 \%$ & $2.53 \%$ \\
Average & $-1.62 \%$ & $-3.13 \%$ & $-5.78 \%$ & $-5.00 \%$ & $-2.69 \%$ & $-3.26 \%$ & $-2.65 \%$ & $-3.45 \%$ \\
\hline
\end{tabular}

Table 7. Average POIC, WACC, ROIC - WACC and EVA of property-concentrated and multi-functional companies during the period 2006-2012

\begin{tabular}{lllll}
\hline & ROIC & WACC & ROIC-WACC & EVA (million RMB) \\
\hline Concentration & $4.46 \%$ & $8.38 \%$ & $-3.92 \%$ & -858.25 \\
Diversification & $6.61 \%$ & $9.12 \%$ & $-2.51 \%$ & -643.89 \\
\hline
\end{tabular}

Table 8. Average POIC, WACC, ROIC - WACC and EVA of SOEs and POEs during the period 2006-2012

\begin{tabular}{lllll}
\hline & ROIC & WACC & ROIC - WACC & EVA (million RMB) \\
\hline SOE & $4.37 \%$ & $9.19 \%$ & $-4.82 \%$ & -907.16 \\
POE & $6.79 \%$ & $7.50 \%$ & $-0.71 \%$ & -546.07 \\
\hline
\end{tabular}


much higher EVA than SOEs. The reason behind this can be explained by the following.

Sheltered by favorable regime and ambiguous relationship with state banks, senior executives of SOEs tend to have lower incentive to maximize shareholders' return. It is revealed by the land records in Beijing that $82 \%$ of land auctions last year was won by SOEs, up from 59\% in 2008. A recent report issued by the National Bureau of Economic Research in Cambridge also found that state-owned developers paid $27 \%$ more than their competitors from private sectors for a comparably equivalent piece of land on average (Bao, Chen 2010). Aggressive land acquisition strategy backed up by state banks' financing aid leads to higher capital employed and ignorance in economic interest creation. In 2009, state-owned banks recorded $\$ 1.4$ trillion loans, almost two times of the previous year. Analysts believe that a large portion of the money was flooded into the property market, resulting in the skyrocketing property prices. Over the past five years, various media have reported that SOEs outbid private property developers to win auctions in prime location and set new record for accommodation value, which is referred as "King of the land". In addition, management and general staff in state-owned developers enjoy better payment and welfare than their counterparts in the private sector if work load and others are equivalent (Tong, Huang 2012). The shareholders' value are not so cared or enhanced owing to the causes listed above. On the contrary, the unfair competition that favors developers with statebacked financing has forced private developers to focus more on investment efficiency in order to survive the crucial game. Therefore, POEs are more efficient than SOEs and hence enjoy a larger EVA.

Having explored the EVA difference between property-concentrated and multi-functional companies, and between SOEs and POEs, we would like to test whether this difference is significant or not. We apply a heteroscedastic t-test to test the following hypotheses:

$\mathrm{H}_{1}$ : The average EVA of multi-functional during 2006-2012 is significantly larger than the average EVA of property-concentrated companies during 2006-2012.

$\mathrm{H}_{2}$ : The average EVA of POEs during 20062012 is significantly larger than the average EVA of SOEs during 2006-2012.

Tables 9 and 10 show the results performed by Excel.

To test the two hypotheses $\mathrm{H}_{1}$ and $\mathrm{H}_{2}$, we perform a one-tailed test. The $\mathrm{p}$-values for one-tailed
Table 9. Results of t-test between average EVA of property-concentrated and multi-functional companies during the period 2006-2012

\begin{tabular}{lll}
\hline & Concentration & Diversification \\
\hline Mean & -858.252985 & -643.886131 \\
Variance & 841833.0067 & 212612.107 \\
$\begin{array}{l}\text { No. of observations } \\
\text { Assumed mean }\end{array}$ & 12 & 6 \\
difference & 0 & \\
Degrees of freedom & 16 & \\
t-statistics & -0.65970556 & \\
P-value (one-tailed test) & 0.259413419 & \\
$\begin{array}{l}\text { Critical value } \\
\text { (one-tailed test) }\end{array}$ & 1.745883669 & \\
P-value (two-tailed test) & 0.518826837 & \\
$\begin{array}{l}\text { Critical value (two-tailed } \\
\text { test) }\end{array}$ & 2.119905285 & \\
\hline
\end{tabular}

Table 10. Results of t-test between average EVA of SOEs and POEs during the period 2006-2012

\begin{tabular}{lll}
\hline & SOE & POE \\
\hline Mean & -907.16 & -546.07 \\
Variance & 757779 & 329985 \\
No. of observations & 12 & 6 \\
Assumed mean difference & 0 & \\
Degrees of freedom & 14 & \\
t-statistics & -1.0505 & \\
P-value (one-tailed test) & 0.15564 & \\
Critical value (one-tailed test) & 1.76131 & \\
P-value (two-tailed test) & 0.31128 & \\
Critical value (two-tailed test) & 2.14479 & \\
\hline
\end{tabular}

tests in both Tables 9 and 10 are greater than 0.05 , showing that at $5 \%$ significant level, both $\mathrm{H}_{1}$ and $\mathrm{H}_{2}$ are rejected, i.e. the average EVA of multi-functional during 2006-2012 is not significantly larger than the average EVA of propertyconcentrated companies during 2006-2012, while the average EVA of POEs during 2006-2012 is not significantly larger than the average EVA of SOEs during 2006-2012, too. The reason for this result can be explained by the following. A number of the selected multi-functional developers involve in typical capital intensive industries, such as railway, telecommunication, mining, etc. All these industries require heavy capital investment in purchasing assets. The return rate is relatively lower compared with the total capital invested. Moreover, property focused developers have been able to accumulate substantial capital benefiting from economy of scale. Financial strengths of these companies enable them to involve in high-end development and manage different projects at the same time thus generate higher operating profit. 
This narrows the EVA gap between propertyconcentrated and multifunctional companies and hence explains why the hypothesis $\mathrm{H}_{1}$ is rejected. The reason that $\mathrm{H}_{2}$ is rejected may be explained by the fact that SOEs are protected by the government. They can obtain financial support from the government and state-owned banks. This lowers their risk and hence WACC. Thus the EVA gap between SOEs and POEs is narrowed.

\section{IMPLICATIONS}

The results in Section 5 show that the average EVA of the 18 selected mainland property companies remained negative during the period 2006-2012. One of the main reasons for this result is related to the nature of property business. By Hui et al. (2007), it takes a much longer time for property companies to realize income from real estate projects. Capital expenses are incurred at the beginning, but revenue will only be collected through sales and rental income when the project is completed. As a result of such non-synchronization, although the project itself is profitable to the company in the long run, negative outcomes would occur in the beginning stages of the project from an accounting perspective. Therefore, the real implication of the negative EVA of the property companies is that the companies are, in fact, undertaking long-term projects which will generate income only in the long run. The increase in total invested capital (IC) as mentioned in Section 5 indicates that the companies are investing more and more on those projects. Hence their EVA became even more negative in 2011 and 2012.

Another reason for the result of negative EVA of the mainland property companies is that capital profit has not been taken into account in NOPAT, leading to understatement of the actual performance of property, both as an investment asset and as a business unit (Ooi, Liow 2002). From Figure 3, the Second-hand House Price Index in Shanghai rose from about 1600 in 2006 to about 2600 in 2012, yielding an annual increase of about $8 \%$ over the period, which is sufficient to bridge the $3.45 \%$ gap between ROIC and WACC (see Table 6). By Ooi and Liow (2002), NOPAT should include all valuation adjustments which affect the balance sheet in order to reflect the true performance of property companies and real estate as an investment. Recognition of unrealized capital appreciation as earnings would mitigate the illusion that property investment destroys value. Furthermore, according to De Villiers (1997), EVA, which is based on accounting profit (a poor proxy for economic profit), is distorted by inflation. In particular, he demonstrated that under inflation, for a firm holding non-depreciable fixed assets with a project duration of, say, four years, the EVA of the firm is understated. De Villiers (1997) derived the adjusted EVA (AEVA), which provides a better estimate of actual profitability under inflation, as an alternative performance measurement tool for companies.

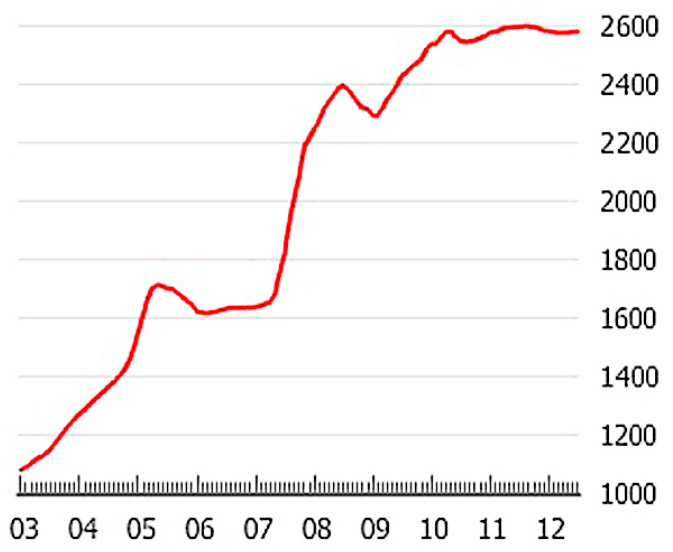

Fig. 3. Second-hand House Price Index, Shanghai $(2003=1000)$

Source: http://www.globalpropertyguide.com/realestate-house-prices/C\#china

Our results also show that multi-functional companies diversifying their businesses enjoyed a higher EVA than those concentrating their businesses on property (see Table 7). This is because the majority of the businesses those multi-functional companies diversifying in do not have such a long period of time of realization of income as real estate projects do (as explained earlier in this section). The companies earn a higher EVA from those businesses and hence their overall EVA is also higher.

Another important result in this study is that POEs earned a much higher EVA than SOEs did (see Table 8). This reflects the inefficiency of SOEs. Although they are protected by the government and can obtain financial support from the government and state-owned banks, the management of SOEs is often inefficient due to large size and bureaucracy. Moreover, SOEs have a lower incentive to increase shareholders' value because they are protected by the government and face little competition. This explains why POEs outperform SOEs in terms of EVA as shown in our results. By letting SOEs go private, the market force and external competition will force the companies to maximize shareholders' value. Furthermore, management efficiency can be improved. In fact, as a policy of 
opening the market, the Chinese government has continued to let some SOEs to go private in recent years. As a result, the market share of SOEs has shrunk steadily over the past decade. This trend of privatization of SOEs will continue in the future.

\section{CONCLUSIONS}

In order to bridge the gap of insufficient previous work on similar topics, this study investigates EVA of 18 mainland property companies from 2006 to 2012. The following are the main results:

1. On average, the companies recorded a negative EVA over the period.

2. Multi-functional companies outperformed companies concentrating on property in terms of EVA.

3. POEs outperformed SOEs in terms of EVA.

Despite China's strong economic growth in recent years, we find that the major mainland property companies experienced a negative EVA throughout the period 2006-2012. However, this does not mean that the companies were really performing poorly during the period. As explained in Section 6, this result is due to the companies undertaking long-term projects, and the companies do not recognize capital gain from property appreciation as income. Hence the EVA of the companies may be understated. Therefore, investors should not rely solely on EVA of the companies. Instead, they should understand the nature of businesses of the companies thoroughly.

China is still in a transition from planned economy to market economy. The behavior of Chinese companies is different from that of companies in developed countries with free markets. For example, SOEs (a particular type of business found in planned economies only) are found to be outperformed by POEs in terms of EVA in this research. Thus this study bridges the gap that EVA of Chinese companies were seldom investigated in previous work. Investors investing in those emerging countries of which the market is not totally free like China should investigate thoroughly into the market characteristics of those countries. Past experience from developed countries may not be applicable to those emerging countries. This study can act as a reference for future studies in EVA of property companies in other emerging economies in the world.

This research has some limitations. Firstly, due to the criteria set in Section 4, only 18 companies are chosen. The performance of the companies not selected in this paper can be further investigated in the future. Secondly, as explained by De Villiers (1997), EVA is distorted by inflation. Instead, AEVA should be used in order to remove the bias of EVA under inflation. The AEVA of mainland property companies may be more reliable than their EVA, and is a useful scope for future research. Furthermore, companies listed in mainland use different accounting standards from those listed in Hong Kong. This would affect our results. Nevertheless, our study still provides a valuable first insight into the performance of major mainland property companies in terms of EVA.

\section{ACKNOWLEDGEMENTS}

We are grateful for the financial support from the PolyU Internal Research Grants (Project \#GYH96, Z02Z and 4-ZZC8).

\section{REFERENCES}

Anctil, R. M.; Jordan, J. S.; Mukherji, A. 1998. Activity-based costing for economic value added, Review of Accounting Studies 2(3): 231-264. http://dx.doi. org/10.1023/A:1018317230647

Bao, B.; Chen, X. 2010. State-owned bidders fuel China's land boom, The New York Times, A1.

Biddle, G. C.; Bowen, R. M.; Wallace, J. S. 1997. Does EVA beat earnings? Evidence on associations with stock returns and firm values, Journal of Accounting and Economics 24(3): 301-336. http://dx.doi. org/10.1016/S0165-4101(98)00010-X

Brewer, P. C.; Chandra, G.; Hock, C. A. 1999. Economic value added $\left(\mathrm{EVA}^{\mathrm{TM}}\right)$ : its uses and limitations, $S A M$ Advanced Management Journal 64(2): 4-11.

Chen, L.; Qiao, Z. L. 2008. Empirical study of integrated EVA performance measurement in China, Canadian Social Science 4(2): 41-48.

Chen, S.; Dodd, J. L. 1997. Economic value added $\left(\mathrm{EVA}^{\mathrm{TM}}\right)$ : an empirical examination of a new corporate performance measure, Journal of Managerial Issues 9(3): 318-333.

De Villiers, J. 1997. The distortions in economic value added (EVA) caused by inflation, Journal of Economics and Business 49: 285-300. http://dx.doi. org/10.1016/S0148-6195(97)00001-5

Demodaran, A. 1999. Value creation and enhancement: back to the future, Contemporary Finance Digest 2(4): 5-52.

Finegan, P. T. 1989. Financial incentives resolve the shareholder-value puzzle, Corporate Cashflow (October): 27-32.

Hui, C. M.; Ooi, T. L.; Wong, K. 2007. Economic performance of property companies in Hong Kong, Journal of Property Research 24(2): 139-157. http://dx.doi. org/10.1080/09599910701440123

Ke, Q. 2008. Are state-owned companies underperforming? A case study of Chinese listed property 
companies, Journal of Real Estate Literature 16(2): 183-200.

Liao, X. F.; Feng, J. W. 2005. An all-around analysis of EVA: an evaluating indicator of operating performance, China-USA Business Review 4(4): 17-21.

Liow, K. H.; Ooi, J. T. L. 2004. Does corporate real estate create wealth for shareholders?, Journal of Property Investment \& Finance 22(5): 386-400. http://dx.doi. org/10.1108/14635780410556870

Makelainen, E. 1998. Economic value added as a management tool, Helsinki School of Economics, Finland.

Milunovich, S.; Tsuei, A. 1996. EVA in the computer industry, Journal of Applied Corporate Finance 9(1): 104-115. http://dx.doi.org/10.1111/j.1745-6622.1996. tb00108.x

O'Hanlon, J.; Peasnell, K. 1998. Wall Street's contribution to management accounting: the Stern Stewart EVA financial management system, Management Accounting Research 9(4): 421-444. http://dx.doi. org/10.1006/mare.1998.0089

Ooi, J. T. L.; Liow, K. H. 2002. Real estate corporations: the quest for value, Journal of Property Investment and Finance 20(1): 23-35. http://dx.doi. org/10.1108/14635780210416246
Peasnell, K. V. 1982. Some formal connections between economic values and yields and accounting numbers, Journal of Business Finance and Accounting 9: 361-381. http://dx.doi.org/10.1111/j.1468-5957.1982. tb01001.x

Sharma, A. K.; Kumar, S. 2010. Economic value added (EVA) - literature review and relevant issues, International Journal of Economics and Finance 2(2): 200-220. http://dx.doi.org/10.5539/ijef.v2n2p200

Tong, S. Y.; Huang, Y. 2012. China's state-owned enterprises in the post-crisis era: development and dilemma. National University of Singapore, East Asian Institute. Available at: http://www.eai.nus.edu.sg [accessed 28 February 2012]

Tully, S. 1993. The real key to creating wealth, Fortune, September 20, 38-50.

Wallace, J. S. 1997. Adopting residual income-based compensation plans: do you get what you pay for?, Journal of Accounting and Economics 24(3): 275300. http://dx.doi.org/10.1016/S0165-4101(98)00009-3

Zheng, X.; Chau, K. W.; Hui, C. M. 2010. Efficiency assessment of listed real estate companies: an empirical study of China, International Journal of Strategic Property Management 15(2): 91-104. http://dx.doi.org /10.3846/1648715X.2011.582739 